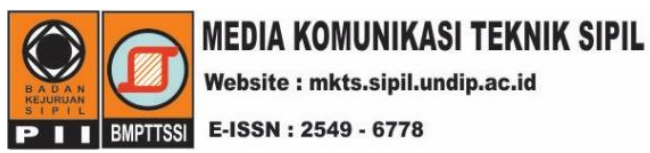

doi: mkts.v25i2.21018

\title{
Uji Beban Timbunan yang Diperkuat dengan Sistem Pelat Terpaku pada Tanah Gambut
}

\author{
"Aazokhi Waruwu ${ }^{1}$, Hary Christady Hardiyatmo², Ahmad Rifa'i ${ }^{2}$ \\ ${ }^{1}$ Fakultas Teknik Sipil dan Perencanaan, Institut Teknologi Medan, Medan, \\ ${ }^{2}$ Fakultas Teknik, Universitas Gadjah Mada, Yogyakarta \\ ${ }^{*}$ azokhiw@gmail.com
}

Received: 12 November 2018 Revised: 7 November 2019 Accepted: 11 November 2019

\begin{abstract}
One of the problems with peat soils, when subjected to imposed loads of construction, is the very high compression and long-term excessive settlement. The embankment can be built on peat soil, but it needs reinforcement that can contribute to increasing the stability of the embankment. The nailed slab system, as reinforcement, is expected to reduce settlement and increase the stability of peat soil. The aim of this paper is to study the effect of pile length and distance on the reduction of settlement in both monolithic and nonmonolithic piles. The embankment load test was conducted on $70 \mathrm{~cm} \times 120 \mathrm{~cm}$ plates, which were reinforced pile with different lengths and distances in the peat soil layer. The analysis was conducted on the reduction settlement of monolithic and non-monolith pile. The results showed that the length and distance of the pile had an effect on the reduction settlement. Changes in pile length are more dominant reducing settlement compared to changes in pile distance. Pile connection with slab has a significant effect on different lengths of piles than different distances piles.
\end{abstract}

Keywords: Peat, nailed slab system, settlement, embankment

\begin{abstract}
Abstrak
Salah satu masalah tanah gambut ketika pelaksanaan konstruksi adalah pemampatannya sangat tinggi dan penurunan berlebih dalam jangka waktu lama. Timbunan dapat dibangun di atas tanah gambut, namun perlu perkuatan yang dapat berkontribusi dalam menambah stabilitas timbunan. Sistem pelat terpaku sebagai perkuatan diharapkan dapat mengurangi penurunan dan meningkatkan stabilitas timbunan di atas tanah gambut. Tujuan makalah ini untuk mempelajari pengaruh panjang dan jarak tiang terhadap reduksi penurunan baik pada tiang monolit maupun tidak monolit. Uji beban timbunan dilakukan pada pelat ukuran $70 \mathrm{~cm} \times 120 \mathrm{~cm}$ yang diperkuat tiang dengan panjang dan jarak yang berbeda pada lapisan tanah gambut. Analisis dilakukan pada reduksi penurunan dari perkuatan tiang monolit dan tidak monolit. Hasil penelitian menunjukkan bahwa panjang dan jarak tiang berpengaruh pada reduksi penurunan. Perubahan panjang tiang lebih dominan mereduksi penurunan dibandingkan perubahan jarak tiang. Ikatan tiang dengan pelat berpengaruh secara signifikan pada tiang dengan panjang yang berbeda daripada tiang dengan jarak yang berbeda.
\end{abstract}

Kata kunci: Gambut, sistem pelat terpaku, penurunan, timbunan

\section{Pendahuluan}

Tanah gambut merupakan salah satu jenis tanah yang mudah mampat dan paling bermasalah sebagai tanah dasar ketika pelaksanaan pekerjaan konstruksi sipil. Penggantian lapisan tanah gambut dengan tanah yang lebih baik dapat dilakukan pada kedalaman tanah gambut yang dangkal. Berikut ini ditampilkan beberapa teknik perbaikan tanah pada tanah gambut. Pembebanan sebelum pembangunan permanennya dilaksanakan yang dikenal sebagai prapembebanan diperlukan pada tanah yang mudah mampat dan tebal seperti tanah gambut.

Prapembebanan dan beban tambahan merupakan salah satu metode yang efektif untuk memperbaiki tanah gambut (Mesri \& Ajlouni, 2007). Jumlah prapembebanan yang diberikan harus cukup, 
sehingga penurunan yang terjadi selama pelaksanaan akan sama dengan penurunan total atau penurunan sisa lebih kecil dari penurunan ijin pasca konstruksi.

Hoque et al. (2004) menerapkan prapembebanan dengan timbunan dari tanah berlanau yang dipadatkan setinggi $3 \mathrm{~m}$ di atas tanah lempung bergambut. Antara tanah dan timbunan diletakan geotekstil dan pasir sebagai perkuatan dan drainase. Timbunan yang besar di atas tanah gambut dapat mengakibatkan kegagalan, karena terjadinya deformasi geser berlebihan dari timbunan daripada pergeseran permukaan, deformasi yang besar bersamaan dengan tension cracks dan heave, terjadinya penurunan tidak seragam dan berlebih akibat daya dukung gambut yang rendah.

Perkuatan berkontribusi dalam menambah stabilitas timbunan, sementara perkuatan dan kuat geser tanah gambut akan menahan gaya lateral yang bekerja (Rowe \& Li, 2005).

Umumnya perkuatan yang digunakan untuk mendukung beban timbunan adalah geosintetik, namun pada penelitian ini menggunakan perkuatan timbunan dari sistem pelat terpaku yang terdiri dari pelat dengan tiang-tiang dari beton.

Hardiyatmo (2008) menyatakan bahwa sistem pelat terpaku cocok digunakan pada tanah yang dipengaruhi penurunan tidak seragam, karena tiang-tiang dapat mengurangi beda penurunan antara pelat sehingga menciptakan permukaan yang lebih rata. Puri et al. (2011) menyatakan bahwa sistem pelat terpaku akan meningkatkan kekakuan pelat dan dapat mereduksi defleksi maksimum seiring dengan penambahan jumlah baris tiang. Tiang-tiang berfungsi untuk menjaga dasar pelat tetap dalam kontak yang baik dengan tanah dasar (Hardiyatmo, 2011).

Pelat-tiang-tanah di sekitarnya menciptakan sistem yang kaku dan lebih tahan terhadap deformasi tanah (Hardiyatmo, 2016). Pemasangan tiang pada pelat berpengaruh dalam mengontrol dan meminimalkan kerusakan yang disebabkan heave pada tanah (Diana et al. 2017).

Sistem fondasi tiang merupakan cara yang efektif untuk menahan beban timbunan dan meminimalkan penurunan total (Meyer \& Shao, 2005). Berdasarkan hasil uji beban pelat didapatkan bahwa penggunaan sistem pelat terpaku sebagai perkuatan pada tanah gambut dapat mereduksi penurunan (Waruwu et al. 2016a).
Hal yang sama didapatkan pada uji beban timbunan yang didukung oleh sistem pelat terpaku dengan ukuran pelat $60 \mathrm{~cm} \times 28 \mathrm{~cm}$ pada tanah gambut (Waruwu et al. 2017a). Pemasangan tiang pada pelat mampu mereduksi penurunan dan meningkatkan modulus reaksi tanah dasar. Tiang dapat mereduksi penurunan, dimana tiang monolit lebih stabil dan kaku daripada tiang tidak monolit. Kecepatan penambahan beban timbunan berpengaruh pada kapasitas dukung sistem pelat terpaku dan karakteristik penurunan tanah gambut (Waruwu et al. 2017b).

Makalah ini melaporkan hasil uji model sistem pelat terpaku akibat beban timbunan pada pelat beton untuk mewakili pelat kaku dan flexiglass untuk mewakili pelat tipis yang fleksibel. Tiang dibedakan monolit dan tidak monolit untuk mengamati pengaruh ikatan tiang dengan pelat. Tujuan penelitian ini untuk mempelajari pengaruh panjang dan jarak tiang terhadap reduksi penurunan baik pada tiang monolit maupun tidak monolit.

\section{Metode}

Uji model sistem pelat terpaku terdiri dari pelat beton dengan dan tanpa tiang-tiang yang dibedakan berdasarkan panjang dan flexiglass dengan dan tanpa tiang pada jarak yang berbeda. Adapun denah dan penampang uji model dapat dilihat pada Gambar 1 dan 2.

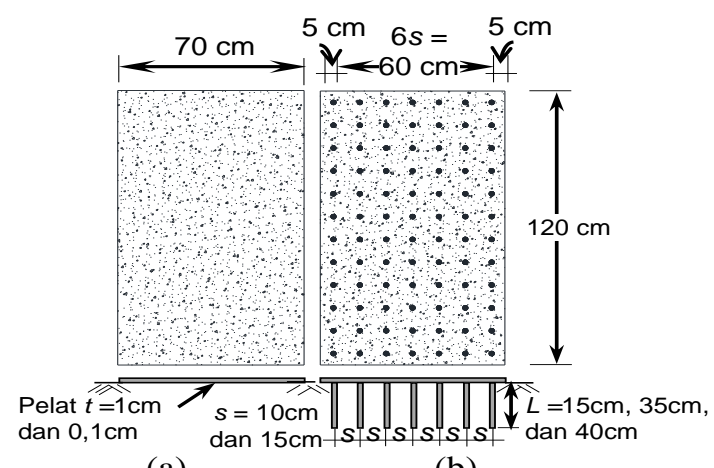

(a)

(b)

\section{Gambar 1. Model uji pada: (a) Pelat beton; (b) Tiang $s=10 \mathrm{~cm}$}

Pelat berukuran luas $70 \mathrm{~cm} \mathrm{x} 120 \mathrm{~cm}$ dengan tebal $2 \mathrm{~cm}$ dan $0,2 \mathrm{~cm}$, masing-masing untuk pelat beton dan flexiglass. Tiang berdiameter $2 \mathrm{~cm}$ pada pelat beton dibedakan menurut panjang tiang $15 \mathrm{~cm}$ dan $35 \mathrm{~cm}$, sementara tiang berdiameter $1 \mathrm{~cm}$ pada flexiglass dibedakan berdasarkan jarak tiang ke tiang masing-masing $10 \mathrm{~cm}$ dan $15 \mathrm{~cm}$. Tiang dengan pelat dihubungkan secara monolit dan tidak monolit. 
Monolit berarti tiang diikat dengan tulangan dan dicor bersamaan dengan pelat, sementara tidak monolit berarti tiang yang dipancang hanya menempel pada dasar pelat.

Media tanah yang digunakan adalah tanah gambut dalam kondisi terganggu dengan nilai berat jenis $\left(G_{s}\right)=1,34$, kadar organik $\left(O_{c}\right)=99 \%$, kadar serat $\left(F_{c}\right)=35,21 \%$, dan kadar abu $\left(A_{c}\right)=1 \%$. Tanah gambut dalam kondisi tidak terganggu memiliki nilai berat volume basah $\left(\square_{b}\right)=10,75 \mathrm{kN} / \mathrm{m}^{3}$, kadar air $(w)=970,86 \%$, dan kuat geser undrained $\left(c_{u}\right)=5,89 \mathrm{kPa}$.

Sampel gambut yang digunakan sama dengan bahan penelitian sebelumnya (Waruwu et al. 2016a; 2016b, 2017a; 2017b). Jenis gambut ini merupakan gambut berserat dengan kadar abu rendah, karena memiliki nilai kadar organik > $75 \%$, kadar serat $>20 \%$, dan kadar abu $<5 \%$.

Bahan tanah gambut yang digunakan, terlebih dahulu dipisahkan dari material yang lebih besar dari $1 \mathrm{~cm}$ dengan cara mengayak pada saringan ukuran $1 \mathrm{~cm} \times 1 \mathrm{~cm}$. Ukuran struktur pada setiap model diharapkan dapat menghasilkan penerapan lapangan dengan ukuran sebesar 10 kali lebih besar dari model penelitian.

Penelitian uji model dilakukan pada bak uji berukuran panjang $700 \mathrm{~cm}$, lebar $350 \mathrm{~cm}$, dan kedalaman $50 \mathrm{~cm}$. Gambut dipadatkan setiap 10 $\mathrm{cm}$ dengan kepadatan mendekati kondisi lapangan. Tiang-tiang dengan diameter, panjang, dan jarak tertentu dipancang dalam tanah gambut.



Model beban timbunan terbuat dari potongan besi berukuran $1,9 \mathrm{~cm} \times 1,9 \mathrm{~cm}$ dan panjang $4 \mathrm{~cm}$. Beban diberikan secara bertahap setiap 3 x 1,9 cm dengan sistem beban loading-unloading yang diterapkan setiap hari sampai pada hari ke empat dan ke lima. Pada saat pembebanan (loading) dan pelepasan beban (unloading) dilakukan pembacaan penurunan menggunakan dial deformasi pada titik dan waktu-waktu tertentu.

Pelaksanaan uji model terlihat pada Gambar 3. Data penurunan dari setiap skema pengujian digunakan untuk menganalisis penurunan dan reduksi penurunan akibat panjang tiang, hubungan tiang dengan pelat, dan jarak tiang.

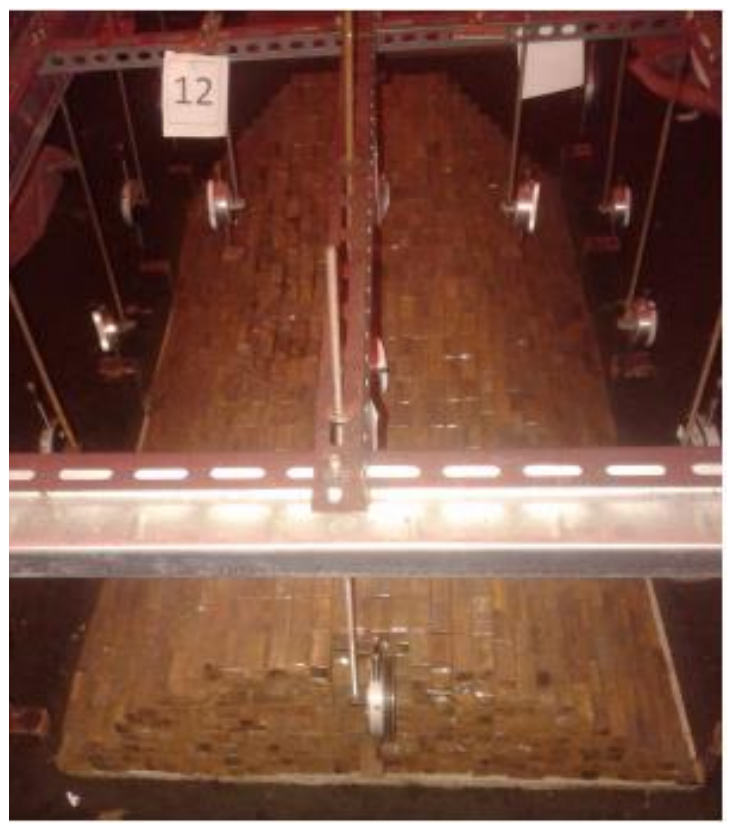

Gambar 3. Uji model sistem pelat terpaku

\section{Hasil dan Pembahasan}

Hasil penelitian memaparkan hasil uji beban timbunan pada pelat beton tanpa tiang dan dengan tiang yang dibedakan berdasarkan panjang. Berdasarkan hasil uji kuat tekan bebas didapatkan nilai kuat tekan $\left(q_{u}\right)=11,78 \mathrm{kPa}$, dengan nilai kuat geser undrained $\left(c_{u}\right)=5,89 \mathrm{kPa}$. Tanah gambut yang digunakan pada penelitian ini digolongkan dalam tanah sangat lunak.

Beban timbunan diberikan secara bertahap dengan tahapan pertama menghasilkan tekanan $4,08 \mathrm{kPa}$, tahapan kedua dengan tekanan total $8,16 \mathrm{kPa}$, tahapan ketiga dengan tekanan total $12,25 \mathrm{kPa}$, dan tahapan keempat dengan tekanan total $16,33 \mathrm{kPa}$. Rasio nilai kuat geser undrained dengan tekanan timbunan didapatkan sebesar $c_{u} / \sigma_{\text {timbunan } 1}=1,44$ untuk tahapan pertama, $c_{u} / \sigma_{\text {timbunan2 }}=0,72$ untuk tahapan kedua, $c_{u} / \sigma_{\text {timbunan } 3}=0,48$ untuk tahapan ketiga, dan $c_{u} / \sigma_{\text {timbunan } 4}=0,36$ untuk tahapan keempat.

Panjang tiang yang digunakan terdiri dari tiang dengan panjang $L=15 \mathrm{~cm}$ dan $L=35 \mathrm{~cm}$, 
sementara ikatan tiang dengan pelat dibedakan tiang monolit dan tidak monolit dengan pelat. Selain hasil uji model pelat beton, hasil uji lain yang diuraikan pada makalah ini adalah uji model pelat tipis fleksibel tanpa tiang dan dengan tiang.

\section{Tanpa tiang}

Hasil uji beban timbunan pada pelat beton dan flexiglass tanpa tiang dapat dilihat pada lendutan setiap tahapan beban timbunan di Gambar 4 dan Gambar 5. Pelat tipis fleksibel mengakibatkan lendutan yang lebih besar daripada pelat beton.

Pelat beton yang lebih kaku terlihat dalam posisi miring jika tidak diperkuat tiang. Pelat tipis fleksibel tidak dalam posisi miring, namun lendutan pelat cukup besar, jika tidak menggunakan perkuatan tiang.

Jarak dari pusat timbunan $(\mathrm{cm})$

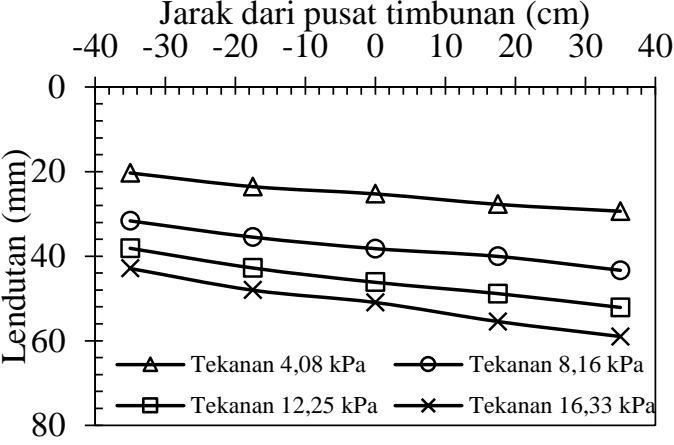

Gambar 4. Lendutan pelat beton pada arah melintang timbunan yang tidak diperkuat tiang

Jarak dari pusat timbunan $(\mathrm{cm})$ $\begin{array}{lllllllll}-40 & -30 & -20 & -10 & 0 & 10 & 20 & 30 & 40\end{array}$

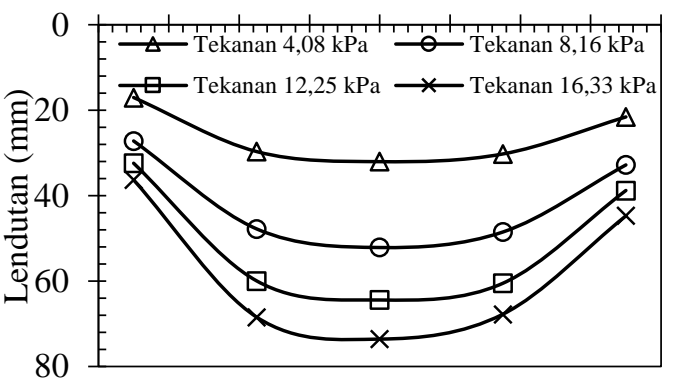

Gambar 5. Lendutan pelat flexiglass pada arah melintang timbunan yang tidak diperkuat tiang

\section{Pengaruh tiang}

Pengaruh tiang terhadap penurunan dapat dilihat pada hubungan rasio kuat geser undrained dengan tekanan akibat beban timbunan $\left(c_{u} / \sigma\right)$ dan penurunan dari hasil uji model pelat beton dengan tiang pada Gambar 6. Beban timbunan yang semakin besar mengakibatkan penurunan yang semakin tinggi. Tekanan akibat beban timbunan yang mendekati sama dengan kuat geser undrained memperlihatkan penurunan yang relatif kecil. Tiang yang memperkuat pelat dapat mereduksi penurunan pelat, pada tekanan yang sama penurunan pelat dengan tiang lebih kecil daripada penurunan pelat tanpa tiang.

Kedua tipe panjang tiang memperlihatkan bahwa tiang yang diikat secara monolit dengan pelat menghasilkan penurunan yang kecil dibandingkan tiang yang diikat secara tidak monolit.

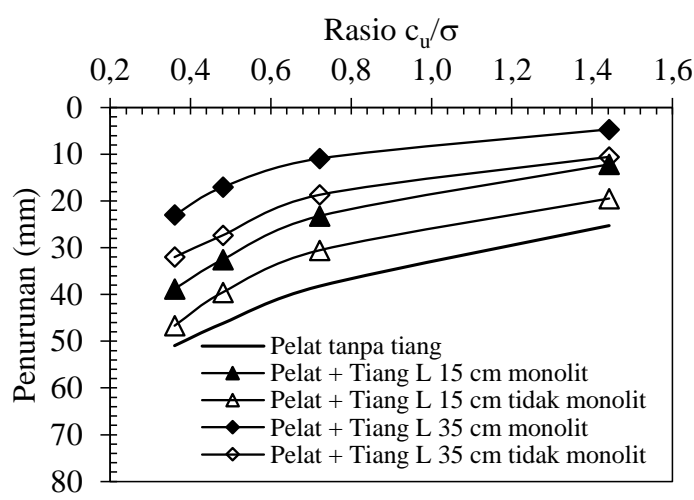

\section{Gambar 6. Penurunan pada timbunan yang diperkuat pelat beton dengan tiang}

Pengaruh panjang tiang terhadap reduksi penurunan dapat dilihat pada Gambar 7. Panjang tiang berpengaruh pada reduksi penurunan pelat, tiang yang lebih panjang memberikan reduksi penurunan yang lebih besar. Hal ini dapat dilihat dari rasio $L / B$ yang lebih besar memberikan reduksi penurunan yang besar juga. Tiang monolit menghasilkan reduksi penurunan yang signifikan daripada tiang tidak monolit.

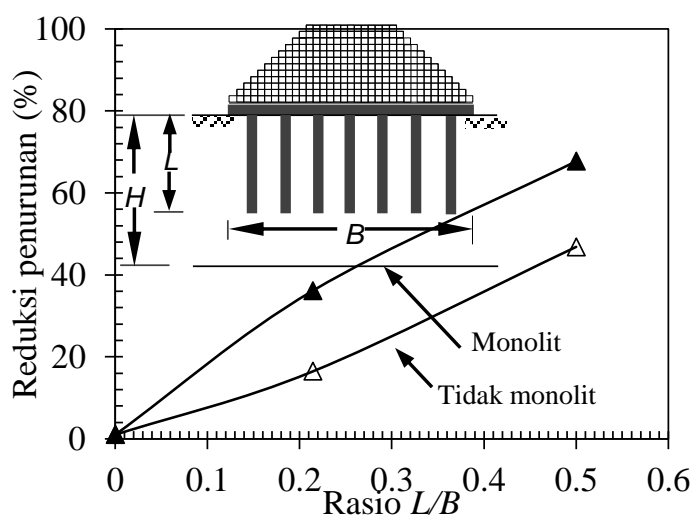

\section{Gambar 7. Reduksi penurunan pada panjang} tiang yang berbeda

Rerata reduksi penurunan untuk tiang monolit (36\% - 68\%) lebih besar daripada tiang tidak monolit $(16 \%-47 \%)$. Reduksi penurunan pada tiang pendek $L=15 \mathrm{~cm}(L / B=0,21)$ didapatkan sebesar $16,45 \%$ untuk tiang tidak monolit dan 
$36,13 \%$ untuk tiang monolit, sementara pada tiang panjang $L=35 \mathrm{~cm}(L / B=0,35)$ sebesar $46,83 \%$ untuk tiang tidak monolit dan $67,72 \%$ untuk tiang monolit. Rerata reduksi tiang monolit terhadap tiang tidak monolit sebesar $24,03 \%$ untuk tiang $L=15 \mathrm{~cm}$ dan $40,76 \%$ untuk tiang $L=35 \mathrm{~cm}$.

Pengaruh tiang terhadap lendutan pelat dapat dilihat pada Gambar 8. Tiang-tiang mampu mengurangi lendutan pelat, tiang-tiang yang dipasang monolit dengan pelat lebih stabil dalam menerima beban. Hal ini dapat dilihat pada perilaku lendutan pelat yang didukung tiang monolit lebih datar daripada tiang yang tidak monolit. Tiang yang diikat secara monolit dengan pelat mengakibatkan sistem pelat terpaku semakin kaku dan stabil dalam mendukung beban timbunan. Pelat tanpa tiang dan dengan tiang tidak monolit cenderung miring dan tidak stabil ketika beban diterapkan.

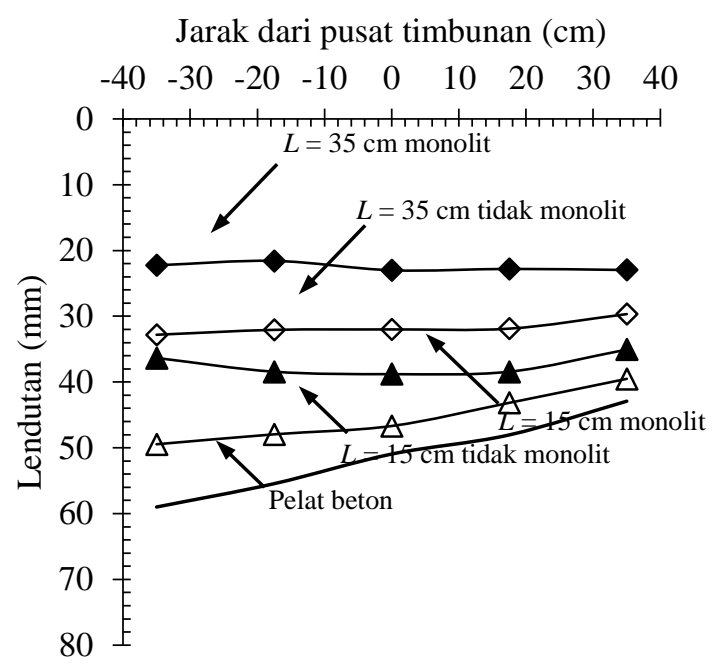

\section{Gambar 8. Pengaruh tiang pada lendutan pelat beton pada arah melintang timbunan}

\section{Pengaruh jarak tiang}

Pengaruh jarak tiang terhadap penurunan dapat dilihat dari hasil uji beban timbunan pada pelat tipis fleksibel tanpa tiang dan dengan tiang yang ditunjukkan pada Gambar 9.

Tiang dengan panjang dan diameter yang sama ( $L$ $=40 \mathrm{~cm}$ dan $d=1 \mathrm{~cm}$ ) dibedakan berdasarkan jarak dan ikatan dengan pelat. Rasio kuat geser undrained dengan tekanan akibat beban timbunan $\left(c_{u} / \sigma\right)$ yang semakin tinggi memperlihatkan penurunan yang semakin kecil. Pengaruh jarak tiang terhadap reduksi penurunan pelat terlihat pada Gambar 10. Jarak tiang berpengaruh terhadap penurunan pelat, tiang dengan jarak $10 \mathrm{~cm}$ menghasilkan reduksi penurunan yang lebih tinggi dibandingkan dengan tiang dengan jarak $15 \mathrm{~cm}$.

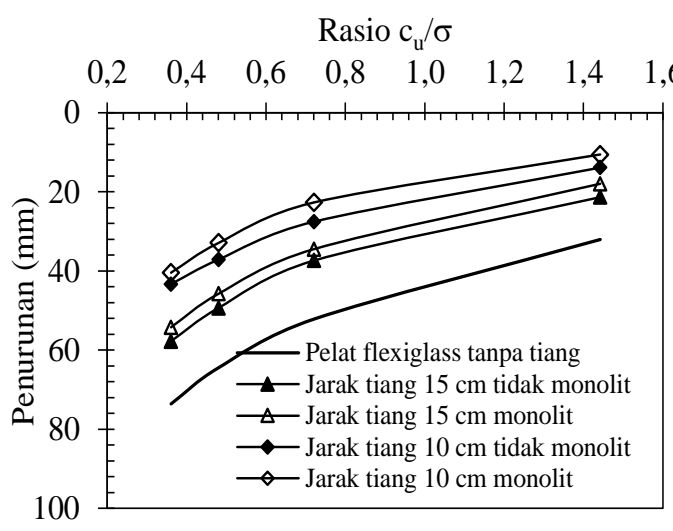

Gambar 9. Penurunan pada timbunan yang diperkuat pelat flexiglass dengan tiang

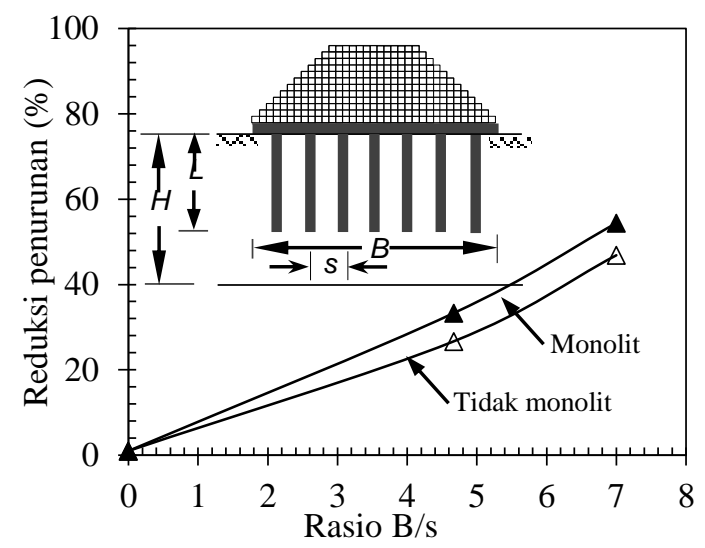

\section{Gambar 10. Reduksi penurunan pada jarak tiang yang berbeda}

Reduksi penurunan pelat dengan tiang monolit didapatkan sebesar $33 \%$ untuk jarak tiang $15 \mathrm{~cm}$ dan $54 \%$ untuk jarak tiang $10 \mathrm{~cm}$, sementara untuk tiang yang tidak monolit didapatkan sebesar $27 \%$ untuk jarak tiang $15 \mathrm{~cm}$ dan $47 \%$ untuk jarak tiang $10 \mathrm{~cm}$.

Rerata reduksi penurunan pada jarak tiang $15 \mathrm{~cm}$ $(B / s=4,67)$ sebesar $26,68 \%$ untuk tiang tidak monolit dan $33,29 \%$ untuk tiang monolit, sementara pada jarak tiang $10 \mathrm{~cm}(B / s=7)$ sebesar $46,86 \%$ untuk tiang tidak monolit dan $54,38 \%$ untuk tiang monolit. Rerata reduksi tiang monolit terhadap tiang tidak monolit sebesar 9,24\% untuk tiang dengan jarak $15 \mathrm{~cm}$ dan $14,87 \%$ untuk tiang dengan jarak $10 \mathrm{~cm}$. Sedangkan pengaruh jarak tiang terhadap lendutan pelat flexiglass ditunjukkan pada Gambar 11. Kecuali reduksi penurunan, tiang-tiang yang dipasang di bawah pelat terlihat berpengaruh terhadap lendutan. Tiang dapat mengurangi lendutan pelat tipis fleksibel. Tiang dengan jarak lebih rapat dan monolit dengan pelat memperlihatkan lendutan yang lebih kecil dibandingkan dengan tiang dengan jarak yang lebih besar dan tidak monolit. 


\section{Pembahasan}

Tanah yang diteliti digolongkan dalam jenis gambut berserat dengan kadar abu rendah. Berdasarkan nilai kuat geser undrained dari uji kuat tekan bebas, tanah gambut tergolong sebagai tanah sangat lunak. Jika dilihat dari hasil pengujian kuat geser menggunakan uji geser langsung didapatkan bahwa nilai sudut gesek tanah $33,22^{\circ}$ dan kohesi sebesar $0,028 \mathrm{~kg} / \mathrm{cm}^{2}$. Nilai sudut geser terlihat cukup besar, hal ini dipengaruhi oleh kadar serat yang tinggi $>20 \%$. Serat mempengaruhi peningkatan gesekan antar butir tanah ketika air dalam pori-pori tanah terdrainase akibat tekanan yang diberikan pada saat uji geser langsung.

Jarak dari pusat timbunan $(\mathrm{cm})$

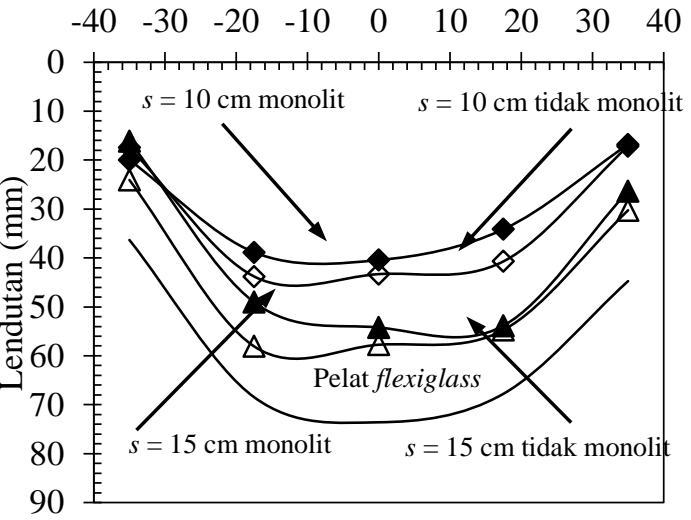

\section{Gambar 11. Pengaruh jarak tiang pada lendutan pelat flexiglass pada arah melintang timbunan}

Berdasarkan uji beban timbunan pada gambut yang diperkuat pelat tanpa tiang didapatkan bahwa pelat beton yang lebih kaku terlihat miring ke salah satu arah, sehingga salah satu tepi mengalami penurunan sedangkan tepi lainnya naik. Hal ini dapat disebabkan karena kapasitas dukung tanah gambut sangat rendah yang dibuktikan dengan nilai kuat geser undrained yang sangat rendah.

Pelat fleksibel yang tidak diperkuat tiang memperlihatkan lendutan yang relatif tinggi di tengah pelat sedangkan lendutan di pinggir pelat terlihat lebih kecil dibandingkan di tengah pelat. Hal ini dapat disebabkan oleh sifat lentur dari material ini mengikuti beban timbunan yang terkonsentrasi di tengah pelat.

Berdasarkan pengujian dari kedua tipe pelat yang tidak diperkuat tiang didapatkan bahwa pelat tanpa tiang tidak cukup kuat menahan beban timbunan. Sistem perkuatan yang tidak stabil berpengaruh pada ketidakstabilan timbunan dan konstruksi lainnya di atas tanah gambut. Dengan demikian diperlukan perkuatan pelat dari tiang-tiang yang dapat mereduksi lendutan dan penurunan, sehingga stabilitas timbunan dapat tetap terjaga.

Hasil uji beban timbunan pada tanah gambut diperkuat sistem pelat terpaku menunjukkan adanya reduksi penurunan yang signifikan dengan pemasangan tiang di bawah pelat. Kedua jenis model pelat yang digunakan memperlihatkan besar penurunan yang berbeda satu sama lain, hal ini dipengaruhi oleh panjang tiang, jarak tiang, dan ikatan tiang yang memperkuat pelat.

Bentuk perubahan penurunan tanah gambut pada pelat tipis fleksibel memiliki kesamaan dengan pelat beton, keduanya menunjukkan perubahan penurunan yang besar di awal pembebanan dan seterusnya semakin kecil dengan bertambahnya beban timbunan (Gambar 6 dan Gambar 9).

Rasio $c_{u} / \sigma<0,8$ memperlihatkan perilaku penurunan yang relatif lebih besar, sedangkan untuk rasio $c_{l} / \sigma>0,8$ menunjukkan penurunan yang relatif konstan. Hal ini terjadi pada kelima tipe pengujian baik pada pelat tanpa tiang maupun dengan tiang. Kuat geser tanah berpengaruh pada daya dukung tanah dalam menahan beban. Semakin tinggi kuat geser tanah, maka penurunan yang terjadi semakin kecil (Gambar 6).

Tiang-tiang yang dipasang monolit dengan pelat lebih stabil dalam menerima beban dibandingkan tiang tidak monolit. Hal ini dapat dilihat pada penurunan pelat yang didukung tiang monolit lebih kecil daripada tiang yang tidak monolit. Selain ikatan tiang dengan pelat, panjang tiang terlihat berpengaruh pada penurunan. Tiang yang lebih panjang dapat meningkatkan kekakuan dan stabilitas dari sistem pelat terpaku dalam menerima beban.

Prapembebanan dapat memperbaiki perilaku pemampatan gambut, hal ini terlihat pada penurunan saat pembebanan kembali (reloading) diterapkan menjadi relatif lebih kecil dan tidak menimbulkan keruntuhan timbunan.

Prapembebanan merupakan suatu metode perbaikan tanah berupa penempatan beban timbunan di atas permukaan tanah yang distabilisasi, berat beban timbunan sekurangkurangnya sama dengan beban permanen dan akan dibongkar pada saat konsolidasi tercapai. Metode ini dimungkinkan untuk digunakan pada perbaikan tanah gambut yang memiliki pemampatan tinggi. Perkuatan dari sistem pelat terpaku dapat digunakan untuk menjamin stabilitas beban timbunan, sehingga tidak mengalami keruntuhan.

Beban timbunan secara bertahap terbukti menaikkan stabilitas timbunan, karena kuat geser 
tanah meningkat akibat konsolidasi setelah tanah gambut mengalami prapembebanan. Penambahan beban timbunan dilakukan secara bertahap untuk membiarkan tanah gambut terkonsolidasi, sehingga kuat gesernya meningkat bersamaan dengan mengalirnya air tanah dalam lapisan gambut.

Timbunan yang besar mengakibatkan tanah menjadi longsor karena daya dukung gambut yang rendah, sehingga tinggi timbunan dicari yang optimum. Pada tekanan akibat beban timbunan yang besar terlihat perubahan penurunan yang semakin kecil pada tanah yang sudah mengalami prapembebanan terlebih dahulu. Kecuali perubahan penurunan yang semakin kecil, timbunan bertahap juga menunjukkan perubahan lendutan yang semakin kecil (Gambar 4 dan 5).

Berdasarkan hasil penelitian ditunjukkan bahwa pemampatan tanah gambut menjadi berkurang secara signifikan setelah diberi prapembebanan. Hasil uji beban timbunan menunjukkan perubahan penurunan yang besar di awal pembebanan dan seterusnya semakin kecil dengan bertambahnya tinggi timbunan.

Sistem pelat terpaku yang telah diuji secara skala kecil pada penelitian ini menunjukkan kinerja yang baik dalam meningkatkan daya dukung, meningkatkan stabilitas sistem dan timbunan, dan mereduksi penurunan. Penurunan tidak seragam ditunjukkan pada permukaan pelat yang tidak rata pada pelat beton tanpa tiang dan pelat yang diperkuat tiang tidak monolit. Sistem pelat terpaku dengan tiang monolit menunjukkan permukaan pelat beton yang tetap rata dengan beda penurunan yang kecil (Gambar 8).

Tekanan akibat beban timbunan yang sama memperlihatkan lendutan pelat yang berbeda pada kedua jenis pelat yang digunakan. Pelat beton yang kaku menunjukkan lendutan yang lebih kecil daripada pelat tipis fleksibel (Gambar 4 dan 5). Pelat beton yang diperkuat tiang-tiang monolit lebih kaku dan stabil dalam menerima beban timbunan daripada pelat tipis fleksibel (Gambar 8 dan 11). Perubahan panjang tiang lebih signifikan dalam mereduksi penurunan daripada perubahan jarak tiang (Gambar 7 dan 10).

Perlawanan gesek tiang semakin tinggi jika tiang semakin panjang, sementara perubahan jarak hanya mempengaruhi perlawanan ujung tiang. Dengan demikian, tiang-tiang yang memperkuat pelat dapat memaksimalkan fungsi mendistribusikan beban melalui kedalaman lapisan dengan memanfaatkan lekatan antara tanah dan permukaan tiang daripada fungsi untuk memindahkan beban timbunan ke lapisan yang lebih keras di bawah lapisan gambut, karena tiang hanya mengapung pada lapisan gambut dan tidak sampai pada tanah keras.

Tiang-tiang yang memperkuat pelat dapat memaksimalkan fungsi untuk mendistribusikan beban timbunan melalui kedalaman lapisan gambut dengan memanfaatkan lekatan antara tanah dan permukaan tiang. Tiang mampu meningkatkan kekakuan sistem, tekanan terdistribusi secara merata di sepanjang lebar pelat, sehingga tekanan di pusat pelat menjadi lebih kecil. Tiang monolit dengan pelat lebih efektif dan lebih baik dalam mereduksi penurunan, memperkaku, dan menjaga stabilitas timbunan. Tiang mengakibatkan tanah di antara tiang di bawah pelat menjadi terkekang, sehingga gerakan lateral berkurang dan penurunan semakin kecil.

Kinerja sistem pelat terpaku sangat menjanjikan untuk diterapkan sebagai perkuatan timbunan pada tanah gambut. Sistem ini berpotensi untuk diterapkan sebagai perkuatan beban timbunan pada jenis tanah lunak lainnya. Sistem pelat terpaku dapat digunakan sebagai alternatif sistem perkuatan pada tanah gambut untuk menahan beban timbunan, beban konstruksi, dan beban kendaraan pada pekerjaan jalan. Hasil yang lebih baik dalam hal reduksi penurunan, reduksi lendutan, dan stabilitas sistem disarankan menggunakan tiang yang diikat secara monolit dengan pelat.

\section{Kesimpulan}

Berdasarkan pembahasan yang telah diuraikan, maka dapat diambil beberapa kesimpulan antara lain: prapembebanan dapat memperbaiki perilaku pemampatan gambut, sehingga penurunan pada saat beban permanen diterapkan menjadi relatif lebih kecil daripada penurunan ijin. Penambahan beban timbunan secara bertahap terbukti dapat menaikkan stabilitas timbunan, karena kuat geser tanah meningkat akibat konsolidasi setelah tanah gambut mengalami prapembebanan.

Rasio kuat geser undrained dengan tekanan akibat beban timbunan $\left(c_{u} / \sigma\right)$ yang semakin tinggi dapat mengurangi penurunan pada tanah gambut. Tiang yang diikat secara monolit dengan pelat menghasilkan reduksi penurunan yang lebih besar dibandingkan tiang yang diikat secara tidak monolit. Rerata reduksi tiang monolit terhadap tiang tidak monolit sebesar $24,03 \%$ untuk tiang $L=15 \mathrm{~cm}$ dan $40,76 \%$ untuk tiang $L=35 \mathrm{~cm}$. Selain reduksi penurunan, tiang-tiang dapat mengurangi lendutan pelat, tiang monolit didapatkan lebih stabil dalam menerima beban 
dibandingkan tiang tidak monolit. Tiang monolit mengakibatkan tanah menjadi terkekang, sehingga gerakan lateral semakin berkurang dan penurunan semakin kecil. Panjang tiang berpengaruh pada reduksi penurunan pelat, tiang yang lebih panjang memberikan reduksi penurunan yang lebih besar. Reduksi penurunan pada tiang $L=15 \mathrm{~cm}$ $(L / B=0,21)$ didapatkan sebesar $16,45 \%$ untuk tiang tidak monolit dan $36,13 \%$ untuk tiang monolit, sedangkan pada tiang $L=35 \mathrm{~cm}(L / B=$ $0,35)$ sebesar $46,83 \%$ untuk tiang tidak monolit dan $67,72 \%$ untuk tiang monolit.

Jarak tiang berpengaruh terhadap reduksi penurunan. Rerata reduksi penurunan pada tiang jarak $15 \mathrm{~cm}(B / s=4,67)$ sebesar 26,68\% untuk tiang tidak monolit dan $33,29 \%$ untuk tiang monolit, sedangkan pada jarak tiang $10 \mathrm{~cm}$ $(B / s=7)$ sebesar $54,38 \%$ untuk tiang monolit dan $46,86 \%$ untuk tiang tidak monolit. Rerata reduksi tiang monolit terhadap tiang tidak monolit sebesar 9,24\% untuk tiang jarak $15 \mathrm{~cm}$ dan $14,87 \%$ untuk tiang jarak $10 \mathrm{~cm}$. Perubahan panjang tiang lebih dominan mereduksi penurunan dibandingkan jarak tiang. Ikatan tiang dengan pelat berpengaruh secara signifikan pada tiang dengan panjang yang berbeda dibandingkan pada tiang dengan jarak yang berbeda. Tiang-tiang yang memperkuat pelat pada Sistem Pelat Terpaku dapat memaksimalkan fungsi untuk mendistribusikan beban timbunan melalui kedalaman lapisan gambut dengan memanfaatkan lekatan antara tanah dan permukaan tiang.

\section{Ucapan Terima Kasih}

Penulis mengucapkan terima kasih kepada Direktorat Riset dan Pengabdian Masyarakat Direktorat Jenderal Penguatan Riset dan Pengembangan - Kementerian Riset, Teknologi, dan Pendidikan Tinggi Republik Indonesia atas bantuan pendanaan dalam pelaksanaan penelitian: Hibah Penelitian Disertasi Doktor Tahun Anggaran 2018.

\section{Daftar Pustaka}

Diana, W., Hardiyatmo, H. C., \& Suhendro, B. (2017). Effect of Pile Connections on the Performance of the Nailed-Slab System on the Expansive Soil. International Journal of Geomate, 12(2), 134-141.

Hardiyatmo, H. C. (2008). Sistem Pelat Terpaku (Nailed Slab) untuk Perkuatan Pelat Beton pada Perkerasan Kaku (Rigid Pavement). Prosiding Seminar Nasional Teknologi Tepat Guna Penanganan Sarana Prasarana, MPSP-FT-UGM, Yogyakarta, (1-7).
Hardiyatmo, H. C. (2011). Method to Analyzethe Deflection of the Nailed-Slab System. International Journal of Civil \& Environmental Engineering, 11(4), 22-28.

Hardiyatmo, H. C. (2016). Alternatif Solusi Pembangunan Perkerasan Jalan pada Subgrade Berdaya Dukung Rendah. Paper dipresentasikan pada Seminar Nasional Geoteknik, Banjarmasin, (1-12).

Hoque, E., Islam, M.S., \& Munshi, M.M.K. (2004). Perfomance of Preloading Applied on a Peaty Clay Deposit. Paper presented at Geotechnical Engineering for Transportation Projects (1991-1999).

Meyer, R.V., \& Shao, Y. (2005). GeogridReinforced and Pile-Supported Roadway Embankment. Paper presented at Contemporary issues in Foundation Engineering (1-13).

Mesri, G., \& Ajlouni, M. (2007). Engineering Properties of Fibrous Peats. Journal of Geotechnical And Geoenvironmental Engineering, 133(7), 850-866.

Puri A., Hardiyatmo, H.C., Suhendro, B., \& Rifa'i, A. (2011). Studi Eksperimental Lendutan Pelat yang Diperkuat Tiang-Tiang Friksi Pendek pada Lempung Lunak. Pertemuan Ilmiah Tahunan XIV HATTI, Yogyakarta, (pp: 317-321).

Rowe, R. K., \& Li A. L. (2005). GeosyntheticReinforced Embankments Over Soft Foundations. Geosynthetics International, 12(1), 50-85.

Waruwu, A., Hardiyatmo, H. C., \& Rifa'i, A. (2016a). Studi Eksperimental Pembebanan Pelat yang Diperkuat Tiang pada Tanah Gambut. Paper dipresentasikan pada Seminar Nasional Geoteknik, Yogyakarta, (pp: 53-59).

Waruwu, A., Hardiyatmo, H. C., \& Rifa'i, A. (2016b). Compressive Behavior of BagansiapiapiRiau Peat in Indonesia. Electronic Journal of Geotechnical Engineering, 21(16), 5217-5227.

Waruwu, A., Hardiyatmo, H. C., \& Rifa'i, A. (2017a). Deflection Behavior of The Nailed Slab System-Supported Embankment on Peat Soil. Journal of Applied Engineering Science, 15(4), $556-563$.

Waruwu, A., Hardiyatmo, H. C., \& Rifa'i, A. (2017b). Behavior of Nailed-Slab System on Peat Soil under Loading. Paper dipresentasikan pada the 1nd Warmadewa University International Conference on Architecture and Civil Engineering, Bali, Indonesia, (pp: 101-107). 